\title{
Impact analysis of the decline of agricultural land-use on flood risk and material flux in hilly and mountainous watersheds
}

\author{
Y. Shimizu ${ }^{1}$, S. Onodera ${ }^{2}$, H. Takahashi ${ }^{3}$, and K. Matsumori ${ }^{3}$ \\ ${ }^{1}$ JSPS Research Fellow, Western Region Agricultural Research Centre, National Agriculture and Food \\ Research Organization, Fukuyama, Japan \\ ${ }^{2}$ Graduate School of Integrated Arts and Sciences, Hiroshima University, Higashi-Hiroshima, Japan \\ ${ }^{3}$ Western Region Agricultural Research Centre, National Agriculture and Food Research Organization, \\ Fukuyama, Japan \\ Correspondence to: Y. Shimizu (shimizuy@affrc.go.jp)
}

Received: 11 March 2015 - Accepted: 11 March 2015 - Published: 11 June 2015

\begin{abstract}
Agricultural land-use has been reduced by mainly urbanization and devastation in Japan. The objective of this study is to evaluate the impact of the decline of agricultural land-use on flood risk and material flux in hilly and mountainous watersheds using Soil Water Assessment Tool. The results indicated that increase of flood risk due to abandonment of agricultural land-use. Furthermore, the abandonment of rice paddy field on steep slope areas may have larger impacts on sediment discharges than cultivated field. Therefore, it is suggested that prevention of expansion of abandonment of rice paddy field is an important factor in the decrease of yields of sediment and nutrients.
\end{abstract}

\section{Introduction}

The changes in increasing of magnitude of flood events which have been observed all over the world could be affected by the altered hydrological dynamics as a result of climate change. The changes in flood risk affects not only human and economic damages such as inundation in the urban area but also material fluxes from watersheds such as sediment and nutrients which are eventually caused eutrophication in downstream (Chang et al., 2001; Bouraoui et al., 2004). However, it is important to consider the combine effects of climate change and land use change because land use change such as urbanization affects to hydrological dynamics as well as climate change effects. The changes in flow volume, material fluxes and timing of discharge from watersheds have been confirmed as the results of the effects of land-use changes in previous studies (Mander et al., 2000; Wheater and Evans, 2009; Tu, 2009). In Japan, total area of agricultural land-use has been decreased as one of main trends of land-use changes. A reason of the land-use change is that farmers have retired from agriculture owing to the ag- ing of the most of farmers. Even though the aged farmers have will to continue to cultivate crops, they no longer can do it on the agricultural land-use with a steep slope such as hilly and mountainous area. For this reason, agricultural land-use which locates in hilly and mountainous areas have been decreased due to the abandonment since 1990 (MAFF, 2010). The most of abandoned agricultural land-use have changed to waste lands which will be eventually changed to forest. The land-use changing may lead to increasing flood magnitude and its frequency because the waste lands are no longer maintained by farmers. Especially, decline of rice paddy may increase flood risk because it has an ability of flood mitigation (MAFF, 2010). Furthermore, it is important to assess the impact of land-use changes in upper-middle stream as well as an assessment of climate change effects in terms of flood risk because the majority of large cities are located on downstream of large rivers such as the coastal alluvial plains. Therefore, the objective of this study is to evaluate the impact of the decline in agricultural land-use on flood risk and material flux in hilly and mountainous watersheds. 


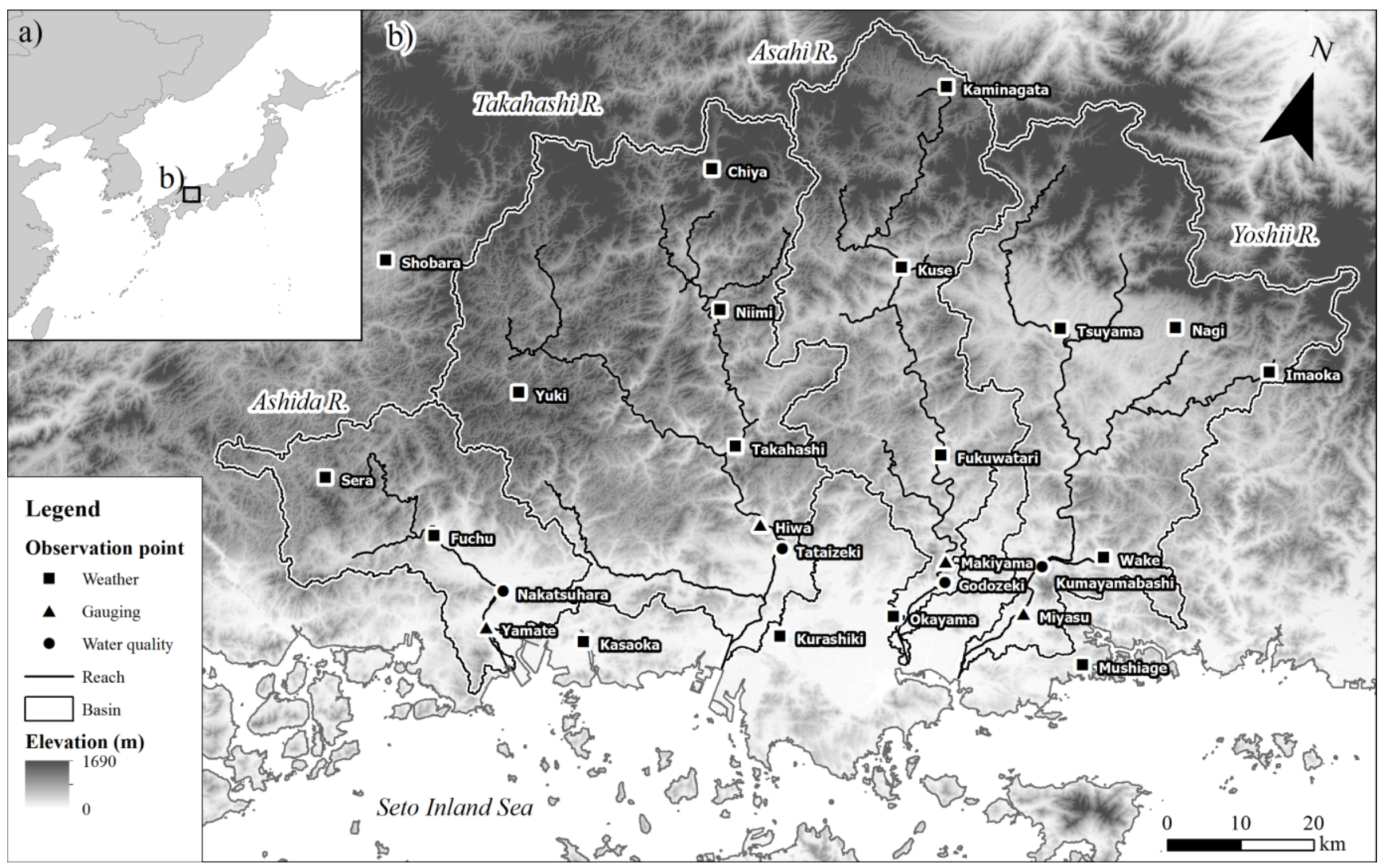

Figure 1. Location of the study watersheds (a) and observed monitoring stations (b).

\section{Methods}

The four watersheds, Takahashi River $\left(2670 \mathrm{~km}^{2}\right)$, Asahi River $\left(1810 \mathrm{~km}^{2}\right)$, Yoshii River $\left(2110 \mathrm{~km}^{2}\right)$ and Ashida River $\left(860 \mathrm{~km}^{2}\right)$ which drain into northern part of the Seto Inland Sea in western Japan, were targeted in this study (Fig. 1). Total areas of agricultural land-use in the watershed are shown in Table 1. The Soil and Water Assessment Tool (SWAT) version 2012 was selected for estimating the changes in flood risks and material fluxes. Evaporation was estimated by the Penman-Monteith method (Monteith, 1965) in SWAT. Geographical data, soil maps, land-use maps and elevation maps required in SWAT were obtained from the following sources. The soil data were obtained from the 1:200000 digital soil maps for Okayama and Hiroshima prefectures by the Ministry of Land, Infrastructure, Transport and Tourism (MLIT). The land-use map with a $100 \mathrm{~m}$ grid was obtained from the national and regional planning bureau of MILT. The elevation map with 3 arcsec pixel resolutions (SRTM V3) was obtained from NASA. Observed daily discharge data at Yamate (Ashida R.), Hiwa (Takahashi R.), Makiyama (Asahi R.) and Miyasu (Yoshii R.) gauging stations were obtained from the Japan River Association. The concentrations of suspended solid (SS), total nitrogen (TN) and total phosphorus (TP) which were observed monthly at Nakatsuhara
Table 1. The total area of agricultural land-use.

\begin{tabular}{lrrrrrrr}
\hline Watersheds & $\begin{array}{r}\text { Watershed } \\
\text { area }\left(\mathrm{km}^{2}\right)\end{array}$ & \multicolumn{2}{c}{$\begin{array}{l}\text { Rice Paddy } \\
\text { field }\left(\mathrm{km}^{2}\right)\end{array}$} & & \multicolumn{2}{c}{$\begin{array}{c}\text { Cultivated } \\
\text { field }\left(\mathrm{km}^{2}\right)\end{array}$} \\
\cline { 3 - 4 } \cline { 7 - 8 } & & & $\begin{array}{r}<\% \\
\text { slope }\end{array}$ & $\begin{array}{r}>5 \% \\
\text { slope }\end{array}$ & & $\begin{array}{r}<5 \% \\
\text { slope }\end{array}$ & $\begin{array}{r}>5 \% \\
\text { slope }\end{array}$ \\
\hline Ashida R. & 860 & 49.7 & 98.2 & & 1.9 & 10.1 \\
Takahashi R. & 2670 & 78.2 & 219.7 & & 10.9 & 100.6 \\
Asahi R. & 1810 & 42.8 & 138.3 & & 10.6 & 46.2 \\
Yoshii R. & 2110 & 123.1 & 184.7 & & 2.6 & 6.9 \\
\hline
\end{tabular}

(Ashida R.), Tataizeki (Takahashi R.), Godozeki (Asahi R.) and Kumayamabashi (Yoshii R.) water quality monitoring stations were obtained from the Japan River Association.

Analysis of land use change impacts were conducted using three scenarios: (1) base scenarios with current land-use situation, (2) urbanization scenarios in alluvial plain, (3) abandonment scenarios of agriculture in mountainous area. Potential abandonment of agricultural land-use was defined by slope steepness: the threshold was set as $5 \%$. 
(a) Ashida River

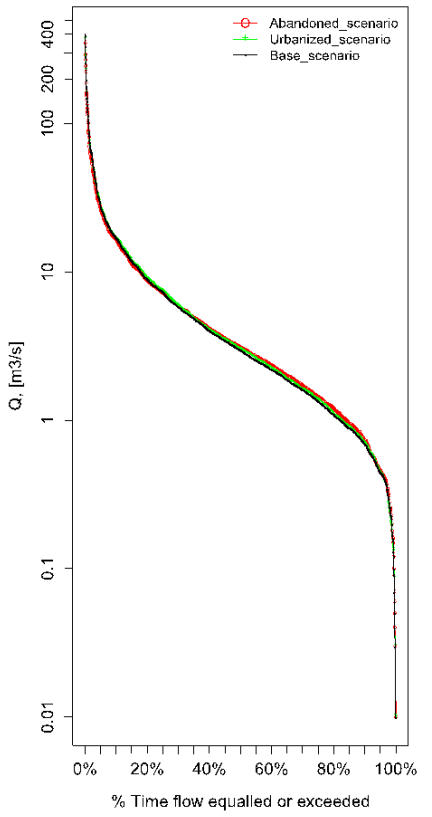

(b) Takahashi River

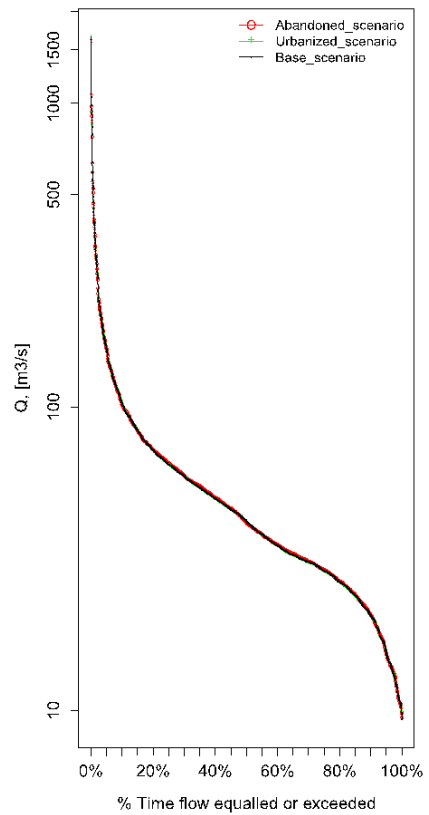

(c) Asahi River

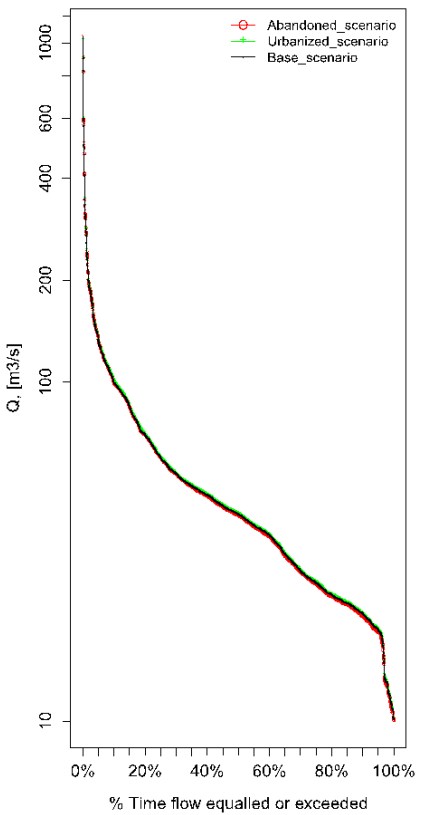

(d) Yoshii River

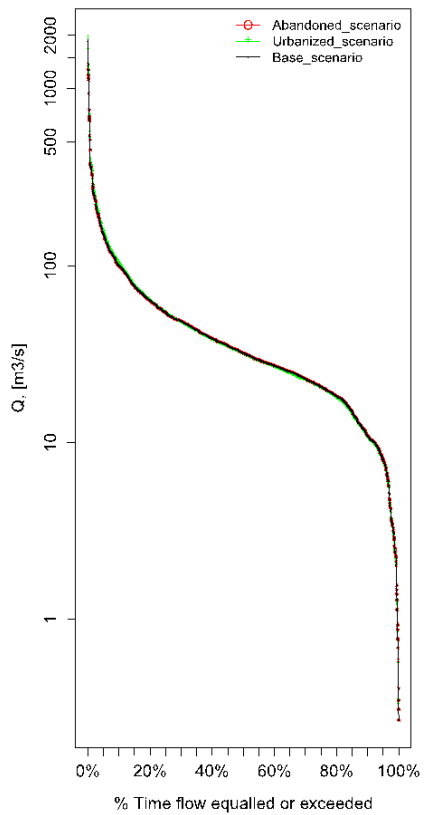

Figure 2. Flow duration curves of each scenarios. (a) Ashida River, (b) Takahashi River, (c) Asahi River, (d) Yoshii River.

\section{Results and discussion}

\subsection{Changes in river discharge}

The model was calibrated for the period from 1995 to 1997 by SUFI2 method using SWATCUP version 5.1.6. The model was validated for the period from 1998 to 1999. The flood risk was assessed for the period from 2000 to 2005. The Nash-Sutcliffe index $\left(E_{\mathrm{NS}}\right)$ (Nash and Sutcliffe, 1970) was used to evaluate the performance of the model. The model performance is shown in Table 2. Figure 2 displays the results of the mean flow duration curve during the period from 2000 to 2005 with different scenarios. Flow duration indices (FDIs) were used to represent the hydrologic responses as an indicator. It is defined as the normalized stream flow that corresponds to the 5,10 and $50 \%$ flow exceedance probabilities $\left(Q_{5}, Q_{10}\right.$ and $\left.Q_{50}\right)$. A result indicates that the flow rate of the base scenario was the lowest flow rate in extreme flow range $\left(>Q_{5}\right.$ ) while the abandoned scenario was the highest flow rate in the range of the Ashida River (Fig. 2a). In contrast, the flow rate of both of the abandoned and urbanized scenarios in the lower range than $Q_{50}$ were lower than the base scenario's flow rate. Although the flow rates of the land-use change scenarios in Takahashi River were slightly fluctuated from the base scenario, results of all of the scenarios were almost similar (Fig. 2b). Effects of the land-use changes may not respond to the hydrological processes in that river due to spatial distribution of the land-uses. The highest flow rate of the Asahi River was found in the urbanization scenario (Fig. 2c). While the flow rates were fluctuated in the high flow range $\left(>Q_{10}\right)$, the estimated flow rates were relatively
Table 2. The Nash-Sutcliffe index values for the validation period.

\begin{tabular}{lcccc}
\hline & $\begin{array}{c}\text { Flow } \\
\text { rate }\end{array}$ & $\begin{array}{c}\text { Suspended } \\
\text { solid }\end{array}$ & $\begin{array}{c}\text { Total } \\
\text { nitrogen }\end{array}$ & $\begin{array}{c}\text { Total } \\
\text { phosphorus }\end{array}$ \\
\hline Ashida R. & 0.84 & 0.73 & 0.70 & 0.71 \\
Takahashi R. & 0.82 & 0.76 & 0.74 & 0.68 \\
Asahi R. & 0.81 & 0.82 & 0.71 & 0.77 \\
Yoshii R. & 0.87 & 0.69 & 0.73 & 0.73 \\
\hline
\end{tabular}

stable. The flow rate of urbanization scenario was less than the base scenario in the range of lower than $Q_{10}$. The abandoned scenario was larger than the base scenario in the same range. The similar trend of this result was found in the results of Yoshii River (Fig. 2d).

Significant changes in mean flow rate were not indicated in any scenarios in the watersheds. Although an increase of mean flow rate of $1.4 \%$ at maximum was found in urbanization scenario in the Ashida River, the changing rates were less than $1 \%$ in the other scenarios. The results of changes in maximum daily flow rate in the scenarios were shown in Fig. 3. The largest change of maximum daily flow rate is an increase of $12.6 \%$ that is found in the abandoned scenario of the Ashida River. The changes in the urbanization scenario of the Takahashi River and Ashida River were 5.6 and $5.5 \%$, respectively. However, significant changes were not indicated in any scenarios of Takahashi River and Asahi River. It was expected that effects of the urbanization scenario on increase of flood risk were larger than the abandoned scenarios because expanding of impervious area may affect to increase 


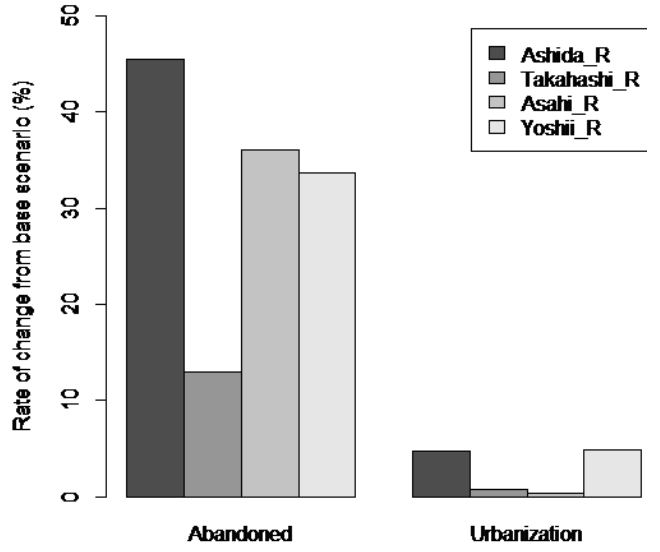

Figure 3. Rate of change in sediment discharge.

of flow rate directly. Against the expectation, the results suggested that the impacts of abandonment of agricultural landuse on increase of flood risk are greater than that of urbanization. The cause of the results are considered that the differences of the total area of agricultural land-use between flat area and a steep slope area are significant. The total area of the land-use on flat areas was smaller than that on steep slope areas because agricultural land-use have been affected by urbanization already. Furthermore, steepness of the slope of agricultural land-use also affects the results. Hence, the results suggest an increase of flood risk due to abandonment of agricultural land-use which locates on a steep slope area in western Japan.

\subsection{Effects of land-use change on flood risks}

The estimated maximum daily sediment discharge of the Ashida River, the Takahashi River, the Asahi River and Yoshii River as base scenarios are 2488, 6966, 1478 and $30470 \mathrm{Mg}$, respectively. Significant increases of sediment discharge are found in the abandoned scenarios; the increase rates of the Ashida River, the Asahi River and the Yoshii River were estimated to be 46,36 and $34 \%$, respectively (Fig. 3). While the result of the Takahashi River indicates an increasing trend of $13 \%$, it is smaller than the other rivers. Although the results of the urbanization scenarios indicated increasing trends in all of the watershed as well as the abandoned scenarios, the increase rates are not significant because all of the increase rates are less than $5 \%$. The main difference between the Takahashi River and the other is the difference of original land-use which was abandoned. The largest area of cultivated field which was abandoned is found in the Takahashi River. Hence, the abandonment of rice paddy field on steep slope areas may have larger impacts on sediment discharges than cultivated field.

The estimated mean nitrogen discharge of the Ashida River, the Takahashi River, the Asahi River and Yoshii River as base scenarios are 391, 1154, 1000 and $2131 \mathrm{Mg} \mathrm{yr}^{-1}$, respectively. The increases of nitrogen yields in the abandoned scenario were found in Ashida River, Asahi River and Yoshii River. The result of Takahashi River only indicated negative trend of $3 \%$. Although all of the results indicated increasing trends in the urbanization scenarios, increase ratios were smaller than that of the abandoned scenario. The increase of the amount of nitrogen in the abandoned scenario was mainly caused by an increase of the organic nitrogen yields except Takahashi River (Fig. 4a). While the contribution of surface runoff to the nitrogen discharge increased in the Ashida River and Asahi River, the contribution of groundwater decreased. The results of urbanization scenarios are indicated clear trends; the increases of organic nitrogen and nitrate yield by surface runoff and the decrease of nitrate yields by lateral flow and groundwater (Fig. 4b). The estimated mean phosphorus discharge of the Ashida River, the Takahashi River, the Asahi River and Yoshii River as base scenarios are $36.2,83.2,62.1$ and $300.0 \mathrm{Mg} \mathrm{yr}^{-1}$, respectively.

A significant increase of organic phosphorus was found in Ashida River and Asahi River as well as the trend of organic nitrogen (Fig. 5a). The largest change rate is found as an increase of $10 \%$ in Ashida River. However, the changes of dissolved phosphorus were not large like organic phosphorus. Both of organic and dissolved phosphorus are indicated increasing trends in all of the urbanization scenarios (Fig. 5b). Increase rate of dissolved phosphorus is larger than organic phosphorus. The large increase rates of organic nitrogen and organic phosphorus are found in the abandoned scenarios of Ashida River and Asahi River. The abandoned area of rice paddy field contributes to yields of organic nitrogen and organic phosphorus. Hence it is suggested that prevention of expansion of abandonment of rice paddy field is an important factor in the decrease of yields of sediment and nutrients.

\section{Conclusions}

The objective of this study is to evaluate the impact of the decline in agricultural land-use on flood risk and material flux in hilly and mountainous watersheds. The results indicated that increase of flood risk was due to abandonment of agricultural land-use. Furthermore, the abandonment of rice paddy field on steep slope areas may have larger impacts on sediment discharges than cultivated field. In addition, the abandoned area of rice paddy field contributes to yields of nitrogen and phosphorus. Especially, increase of sediment yield could affect the occurrence of inundation inside of levee directly because it deposits on river channel or kinds of small weirs on the channel. The flood risk of a near future in western Japan may increase due to abandonment of agricultural land-use as well as climate change effects. Therefore, it is important to prevent increase of sediment yields for decreasing flood risk. Moreover, it is suggested that prevention of expansion of abandonment of rice paddy field is an important factor 

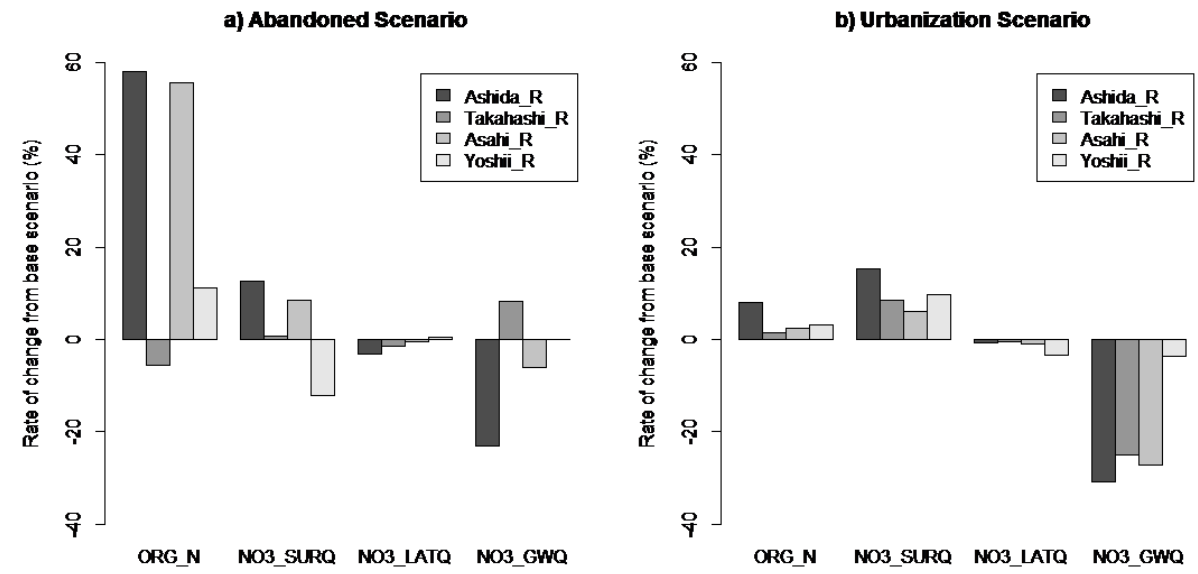

Figure 4. Rate of change in nitrogen discharge in different pathways. (a) Abandoned scenario, (b) urbanization scenario.
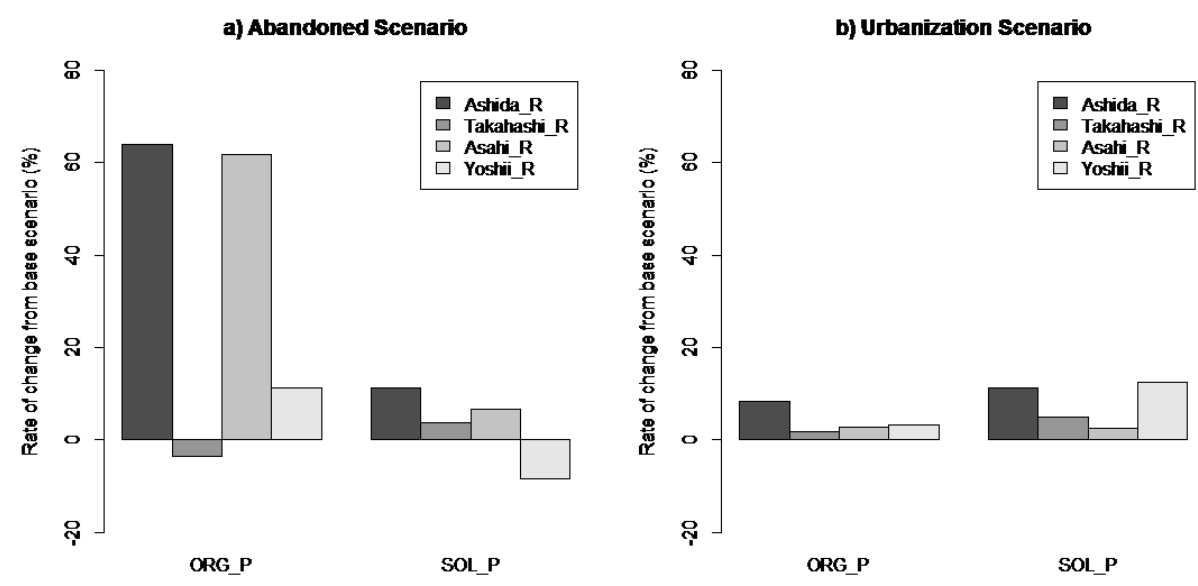

Figure 5. Rate of change in phosphorus discharge in different pathways. (a) Abandoned scenario, (b) urbanization scenario.

in the decrease of yields of sediment and nutrients. However, this study has a limitation in terms of model structure. The dynamics of rice paddy field were mimicked like real condition in this study because the current SWAT model could not express rice paddy field as previous studies pointed out (Xie and Cui, 2011; Sakaguchi et al., 2014). Hence the results on a rice paddy field are possible to be underestimated owing to the failure of water management.

Acknowledgements. This study was supported by Grant-in-Aid for JSPS Fellows Grant Number 13J07499 and Grant-in-Aid for Young Scientists (B) Grant Number 26870837.

\section{References}

Bouraoui, F., Grizzetti, B., Granlund, K., Rekolainen, S., and Bidoglio, G.: Impact of climate change on the water cycle and nutrient losses in a Finnish catchment, Climatic Change, 66, 109-126, 2004.

Chang, H., Evans, B. M., and Easterling, D. R.: The effects of climate change on stream flow and nutrient loading, J. Am. Water Resour. Assoc., 37, 973-985, 2001.

Mander, U., Kull, A., Kuusemets, V., and Tamm, T.: Nutrient runoff dynamics in a rural catchment: Influence of land-use changes, climatic fluctuations and ecotechnological measures, Ecol. Eng., 14, 405-417, 2000.

MAFF - Ministry of Agriculture, Forestry and Fisheries: current trends and issues of abandoned farmlands, MAFF Press, Tokyo, 1-53, 2010.

Monteith, J. L.: Evaporation and the environment, in: The State and Movement of Water in Living Organisms, 19th Symposium, Soc. For Exp. Biol., Cambridge University Press, Swamsea, 205-234, 1965. 
Nash, J. E. and Sutcliffe, J. V.: River flow forecasting through conceptual models, Part I - A discussion of principles, J. Hydrol., 10, 282-290, 1970.

Sakaguchi, A., Eguchi, S., Kato, T., Kasuya, M., Ono, K., Miyata, A., and Tase, N.: Development and evaluation of a paddy module for improving hydrological simulation in SWAT, Agr. Water Manage., 137, 116-122, 2014.

$\mathrm{Tu}, \mathrm{J} .:$ Combined impact of climate and land use changes on streamflow and water quality in eastern Massachusetts, USA, J. Hydrol., $379,268-283,2009$.
Wheater, H. and Evans, E.: Land use, water management and future flood risk, Land Use Policy, 26, S251-S264, 2009.

Xie, X. and Cui, Y.: Development and test of SWAT for modeling hydrological processes in irrigation districts with paddy rice, $\mathrm{J}$. Hydrol., 396, 61-71, 2011. 